\title{
Building opportunities for College Completion in the U.S.: The Arizona State University and Starbucks Partnership
}

\section{Mr. Jeffrey S. Goss, Arizona State University}

Jeffrey Goss has served as the Executive Director for the Office of Global Outreach and Extended Education and Assistant Dean in the Ira A Fulton Schools of Engineering at Arizona State University for the past seven years.

Mr. Goss has more than 18 years experience in professional and executive education collectively at University of Maryland, George Washington University, University of Michigan, and Arizona State University. At ASU's Fulton School of Engineering, Mr. Goss leads Global Engagement, ASU Engineering Online graduate degree programs, and Executive/Professional Development programs. His research areas include global workforce development learning models and the development and application of new technologies and distributed-media models for adult learning.

Since 2010, Mr. Goss has been the Principal Investigator/Project Director for the Higher Engineering Education Alliance Program (HEEAP), focused on modernization and transformation of teaching and learning in undergraduate engineering programs in Vietnam. In this role he has worked in both Vietnam and the United States on faculty and curriculum development to advance Vietnam's economic growth. He has strong relationships with senior officials in the Ministry of Education and Training and the Ministry of Industry, Invalids and Social Affairs, as well as leaders of the high-tech industry in Vietnam. Mr. Goss also has extensive experience in the administration of sub-agreements. Under an existing project funded by USAID and Intel, Mr. Goss has partnered with five major universities in Vietnam to prepare faculty to excel in teaching students to attain technical expertise, English, and the soft skills and competencies to succeed on a global engineering stage.

He received his BS in Public Relations and Management from Central Michigan University (Mt. Pleasant, MI) and Master of Arts Degree in Higher Education Administration from George Washington University (Washington, DC).

Under Mr. Goss' direction, thousands of global engineering professionals from various corporate organizations have advanced their companies and employee's careers with training through executive seminars, certifications, short courses and media distributed graduate degree programs.

\section{Dr. Philip Regier, Arizona State University}

Dr. Philip Regier is University Dean for Educational Initiatives and CEO of EdPlus at ASU. 


\section{Starbucks College Achievement Plan: An Innovative Educational Partnership}

On June 16, 2014, the largest public university in the country and the largest coffee brand in the world announced a first-of-its-kind partnership designed to expand access to higher education. Through the Starbucks College Achievement Plan, Starbucks partners in the U.S. who work as little as 20 hours a week can finish a bachelor's degree with full tuition reimbursement through any of Arizona State University's (ASU's) more than 40 online degree programs. There is no obligation for partners to stay at Starbucks after they graduate from ASU.

The partnership between Starbucks and ASU originated through participation in the Markle Economic Future Initiative, which is co-chaired by Starbucks CEO, Howard Schultz. ASU's president Michael Crow is one of its members. The partnership is grounded in social embeddedness that provides opportunities for Starbucks, ASU and, most importantly, the thousands of students who wouldn't otherwise have the opportunity to earn a college degree. And while this innovative corporate/public university partnership offers a new model for education access, which both Starbucks and ASU are very proud of, it is also a partnership forged on the shared values of our people.

\section{Why Education?}

For Starbucks to be successful in its mission "to inspire and nurture the human spirit - one person, one cup and one neighborhood at a time," its business depends on bright, warm baristas who are able to make an emotional connection with customers. In fact, how Starbucks takes care of its partners matters more to its customers than many traditional corporate responsibility activities undertaken by the company. In 1987, Starbucks was the first corporation to offer healthcare to part-time workers. It was a radical move then, and one that was followed by many other companies over time.

Currently, Starbucks has 135,000 people working in the U.S, the vast majority of whom do not have a college degree. In 2013, Starbucks' leaders decided they wanted to provide something as ambitious as its 1987 healthcare benefits decision to the current generation of partners; something that would continue to attract bright, talented people, and, again, be a shift other companies might eventually emulate. Starbucks wanted to remove barriers for its partners to earn a bachelor's degree. What partners majored in didn't matter - what mattered was completing a degree. Starbucks is committed to its partners' degree attainment regardless of their desire to remain with the company after they graduate.

As Starbucks leaders pushed to place higher education back in reach for their partners, they saw promise in online education. Online appeared particularly well suited to working adults who already had some college experience. Starbucks pursued an education partner that offered highquality online programs, was nonprofit, and was able to work at the scale necessary to serve their large population. They found surprisingly few players who had the quality, scale and commitment necessary to be successful. The online higher education market was still dominated by for-profit online institutions with big marketing budgets, and that wasn't the fit Starbucks was looking for. Many public and private universities, on the other hand, had just a few degree 
programs offered entirely online, and few institutions had committed to offering online programs at a scale that could serve Starbucks' partners.

\section{New Frontiers}

Howard Schultz grew Starbucks to Fortune 500 status in Seattle, and he was well aware that while the rest of the country was looking at New York or Silicon Valley, amazing things could be achieved in places still forming and growing. The Arizona desert has its own frontier spirit, and has offered opportunities for individuals like Michael Crow to implement a vision for a new model of what an American university can be.

ASU, rooted in Arizona, is also committed to addressing issues of national need, including university degree attainment. In 1996, the United States led all OECD countries in adult degree attainment. ${ }^{2}$ By 2011, the United States ranked fourth overall (behind Canada, Japan and Israel). ${ }^{3}$

This trend belies larger problems for higher education and the economy:

1. When stratified by age, in 2011 the United States was $13^{\text {th }}$ among OECD/G20 countries in the percentage of 25- to 34 -year olds with higher education credentials. ${ }^{4}$

2. 43 percent of first-time, full-time undergraduate students who began a public college or university bachelor's degree in 2006 did not complete within six years. 5

3. In 2012, the number of 25- to 34-year-olds with some postsecondary education but no degree was larger than the entire undergraduate enrollment in four-year public institutions. $^{6}$

4. Real income disparity between high school graduates and college/university graduates has increased 135 percent since $1965 .^{7}$

At a time when the benefits of a college/university education have never been higher, the country has stalled in degree completion. Millions of Americans have started a degree but failed to graduate - and, more specifically, failed to graduate before life intervened in one of many forms: unmanageable student debt obligations, vanishing parental support, children or other dependents, and/or the need to provide care for elderly parents or other relatives. These are hard working and academically capable individuals who have no clearly available pathway to earn a high-quality, rigorous degree.

ASU is committed to providing educational opportunities to these adult re-entry learners, ${ }^{8}$ dedicating itself to developing the tools and resources nontraditional students need to be successful. By partnering with companies, entrepreneurs and innovators, community colleges and tool developers, ASU learned how to partner, how to work at scale, how to integrate technologies and how to move quickly to improve services to meet the needs of our students. Since 2010, ASU has used this approach to rapidly develop its online degree programs, providing broad access to a research-based, discovery driven university education. In the process, the university has expanded its ability to deliver degree programs at scale.

Forging the Partnership 
In the fall of 2013, Starbucks' leadership shared their initial ideas with ASU. From the beginning, both sides found common values. For Starbucks, it was ASU's focus and ability to provide high-quality education at scale, along with its willingness to partner in innovating a new model of education access. ASU recognized Starbucks' clear interest in providing its partners with a full undergraduate experience that promised no restrictions on employment following the completion of a degree. It became very apparent that Starbucks is as committed to its partners as ASU is to the welfare of our students and how they succeed at the university and beyond.

The partnership would be one of mutual shared impact. It needed to work at scale, which Starbucks provides. Starbucks partners are relatively young, but demographically reflect America. The partners were hit hard by the Great Recession, and they collectively reflect the degree attainment crisis facing the United States. They offered ASU the opportunity to prove that its initiatives in partnership and online learning at scale would work in service to a large number of students that reflect the diversity, opportunity and challenges faced by America.

There are very few companies in the country that have the capacity to tell a story, develop a narrative and get eyes onto a product, a cause or an issue. Apple does it with product announcements supported by intense advertising; Starbucks does it in much more subtle ways: in their stores, on Facebook, through their baristas, by selling music around a cause, by writing "come together" on their cups. And, on occasion, they launch an initiative that brings national attention simply because of the dynamism, credibility and positive reputation of Starbucks and Howard Schultz. The Starbucks partnership brought ASU a national platform on which to tell its story, and the ability to learn from one of the best companies in the world at communicating that story.

In early 2014, Starbucks' Board of Directors and ASU's Board of Regents approved the Starbucks College Achievement Plan moving forward. Starbucks and ASU quickly mobilized teams to build the infrastructure of the program, preparing to introduce it to partners and the public. Code named "Project Rover" in honor of NASA Rovers Spirit and Opportunity, which carry ASU technology to help us better understand Mars, the program's teams worked together in the lead up to June 16, 2014 when Howard Schultz, Michael Crow and Arne Duncan, U.S. Secretary of Education, made the announcement about the College Achievement Plan in New York City.

Starbucks and ASU are providing a uniquely supportive environment for balancing meaningful work with education. Partners have a dedicated enrollment coach, academic advisor and team of financial aid counselors to support them through graduation.

Before starting classes, partners take ASU 10 - Connect: ASU Orientation, a one-week, noncredit course. Here, partners learn about ASU's mission and polices, discover the value of a university degree from a research institution, explore the tools used in online courses and identify key components of a work/life/school balance plan.

In October, over 1,000 Starbucks partners (nearly a quarter in disciplines within ASU's Ira A. Fulton Schools of Engineering) enrolled in the inaugural session of the College Achievement 
Plan, an impressive number given the short timeframe from the time of announcement to the first application deadline.

At the end of the first session, preliminary results are very encouraging. Despite being slightly less prepared academically than ASU's traditional online student population, Starbucks partners are retaining at a higher rate than our traditional online student population. At ASU's fall 2014 commencement, a long-time Starbucks partner and online ASU student became the first person to graduate with the support of the College Achievement Plan.

Together, Starbucks and ASU share the vision that inclusion is no barrier to excellence - that everyone deserves the opportunity to get a great education. The initiative is committed to expanding opportunities that help Americans succeed in the global digital economy and reignite faith that the American Dream is achievable. It is an innovative corporate/public university partnership that offers a new model for education access.

${ }^{1}$ To learn more about Starbucks mission, see: http://www.starbucks.com/about-us/company-information/missionstatement

${ }^{2}$ OECD (1998), Education at a Glance: OECD Indicators 1998, OECD Publishing (Table a1.2a, p.44). The Organization for Economic Cooperation and Development (OECD) includes most European countries in addition to the United States, Canada, and Japan. Note that with the 200 edition, the OECD changed from reporting university degree attainment to measuring tertiary degree attainment to conform to classifications in the revised International Standard Classification of Education (ISCED/1997).

${ }^{3}$ Population that has attained tertiary education (2011), Table A1.3a, Education at a Glance 2013: OECD Indicators, p. 37.

${ }^{4}$ Institute of Education Sciences, National Center for Education Statistics, U.S. Department of Education, "Institutional Retention and Graduation Rates for Undergraduate Students," The Condition of Education 2014, http://nces.ed.gov/programs/coe/indicator cva.asp.

${ }^{5}$ Population that has attained tertiary education (2011), Table A1.3a, Education at a Glance 2013: OECD Indicators, p. 37.

${ }^{6}$ Public four-year enrollment of 8,092,683 is provided in the Digest of Education Statistics from the National Center for Education Statistics (http://nces.ed.gov/programs/digest/). In 2012, the number of Americans 25-to-34 years old who had attened college but not received a degree was 9,885,542 according to the 2012 American Community Survey, produced by the U.S. Department of Commerce, Census Bureau, and available from Table B15001 of American Fact Finder (http://factinder2.census.gov/faces/nav.jsf/pages/index.xhtml).

${ }^{7}$ Andrea Caumont, “6 Key Findings about Going to College,” Fact Tank, February 11, 2014, http://www.pewresearch.org/fact-tank/2014/02/11/6-key-findings-about-going-to-college/.

${ }^{8}$ To learn more about ASU's Charter and Goals, see: http://president.asu.edu/about/asucharter 